\title{
CHAUCER AND THE ART OF STORYTELLING
}





\section{CHAUCER AND THE ART OF STORYTELLING}

L.EONARD MICHAEL KOFF

University of California Press BERKELEY LOS ANGELES LONDON 
University of California Press

Berkeley and Los Angeles, California

University of California Press, Ltd.

London, England

(C) 1988 by

The Regents of the University of California

Library of Congress Cataloging-in-Publication Data

Koff, Leonard Michael.

Chaucer and the art of storytelling.

Bibliography: p.

Includes index.

1. Chaucer, Geoffrey, d. 1400 . Canterbury tales.

2. Chaucer, Geoffrey, d. 1400-Technique. 3. Storytelling in literature. I. Title.

$\begin{array}{llll}\text { PR 1875.S75K64 } 1988 & 821^{\prime} .1 & 87-19099\end{array}$

ISBN 0-520-05999-9 (alk. paper)

Printed in the United States of America

$\begin{array}{lllllllll}1 & 2 & 3 & 4 & 5 & 6 & 7 & 8 & 9\end{array}$ 
To my father and

the memory of my mother 
